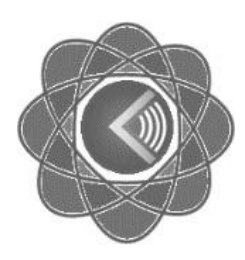

KOMUNIKA, P-ISSN [2615-112X], E-ISSN [2615-5206] http://ejournal.radenintan.ac.id/index.php/komunika

\title{
PENGARUH SUPERVISI AKADEMIK TERHADAP KINERJA GURU MTs MUHAMADIYAH SUKARAME BANDAR LAMPUNG
}

\author{
Eti Hadiati \\ Universitas Islam Negeri Raden Intan Lampung \\ Etihadiati@gmail.com
}

Abstract: $\quad$ The research objective is to find out how much influence academic supervision has on the work performance of Muhammadiyah Sukarame Bandar Lampung Private MTs teachers. While its usefulness is expected to be useful for teachers in order to improve teacher performance related to teacher competence both pedagogical and professional competencies especially teachers of Private MTs Muhammadiyah Sukarame Bandar Lampung which can be used as a reference to improve teacher performance.

Abstrak: $\quad$ Tujuan penelitian adalah untuk mengetahui seberapa besar pengaruh supervisi akademik terhadap kinerja kerja guru MTs Swasta Muhammadiyah Sukarame Bandar Lampung. Sedangkan kegunaannya diharapkan dapat bermanfaat bagi guru-guru dalam rangka untuk meningkatkan kinerja guru yang berkaitan dengan kompetensi guru baik kompetensi paedagogik maupun kompetensi profesional hususnya guru MTs Swasta Muhammadiyah Sukarame Bandar Lampung yang mana dapat digunakan sebagai acuan untuk meningkatkan kinerja guru.

Kata Kunci: $\quad$ Supervisi, Kinerja Guru, Pendidikan 


\section{A. Pendahuluan}

Undang-undang Republik Indonesia No. 20 tahun 2003 tentang sistem pendidikan nasional pada pasal 3 menyebutkan bahwa pendidikan nasional bertujuan untuk berkembangnya potensi peserta didik agar menjadi manusia yang beriman dan bertakwa kepada Tuhan yang Maha Esa, berakhlak mulia, sehat, berilmu, cakap, kreatif, mandiri, dan menjadi warga negara yang demokratis serta bertanggung jawab. ${ }^{1}$ Untuk mewujudkan tujuan pendidikan tersebut maka salah satu faktor penentunya adalah pendidik atau yang sering disebut dengan seorang guru.

Guru sebagai tenaga pendidik merupakan pemimpin pendidikan, dia amat menentukan dalam proses pembelajaran di kelas, dan peran kepemimpinan tersebut akan tercermin dari bagaimana guru melaksanakan peran dan tugasnya. Ini berarti bahwa kinerja guru merupakan faktor yang amat menentukan bagi mutu pembelajaran/pendidikan yang akan berimplikasi pada kualitas output pendidikan setelah menyelesaikan sekolah.

Kinerja guru pada dasarnya merupakan unjuk kerja yang dilakukan oleh guru dalam melaksanakan tugasnya sebagai pendidik. Kualitas kinerja guru akan sangat menentukan pada kualitas hasil pendidikan. Karena guru merupakan pihak yang paling banyak bersentuhan langsung dengan peserta didik dalam proses pendidikan/pembelajaran di lembaga pendidikan madrasah atau sekolah.

Muhtar mengatakan bahwa kinerja guru adalah seluruh aktivitas yang dilakukannya dalam mengemban amanat dan tanggung jawabnya dalam 2013), h. 7

Undang-Undang SISDIKNAS (UU RI No 20 Th.2003), (Jakarta : Sinar Grafik, 
mendidik, mengajar dan membimbing, mengarahkan, dan memandu peserta didik dalam mencapai tingkat kedewasaan dan kematangannya. ${ }^{2}$

Berdasarkan pendapat tersebut maka kinerja guru itu adalah merupakan seluruh aktivitas atau kegiatan yang harus dilakukan oleh guru dalam mendidik peserta didiknya juga bertugas mengajar dan membimbing serta mengarahkan peserta didik untuk menuju kedewasaan dan kematangan. Kehadiran guru dalam proses pembelajaran di sekolah masih tetap memegang peranan yang penting. Peran tersebut belum dapat diganti dan diambil alih oleh siapapun. Hal ini disebabkan karena masih banyak unsur-unsur manusiawi yang tidak dapat diganti oleh unsur lain.

Keberhasilan kinerja guru akan tampak hal ini tidak terlepas dari faktor-faktor yang mempengaruhi kinerja tersebut salah satunya adalah adanya supevisi yang dilakukan oleh pengawas atau kepala sekolah/madrasah. Supervisi oleh pengawas sekolah meliputi supervisi manajerial yang berhubungan dengan aspek pengelolaan dan administrasi sekolah, dan supervisi akademik yang berhubungan dengan aspek pelaksanaan proses pembelajaran. Supervisi akademik dilakukan oleh pengawas, kepala sekolah, dan guru yang ditugasi oleh kepala sekolah untuk melakukan tugas sebagai penyelia. Untuk melakukan supervisi akademik agar dapat dilakukan dengan sistematis maka perlu disusunnya panduan instrumen supervisi akademik tersebut. 2003), h. 84

${ }^{2}$ Muhtar, Desain Pembelajaran Pendidikan Agama Islam, (Jakarta : Misaka Galiza, 
Supervisi akademik adalah bantuan profesional kepada guru, melalui siklus perencanaan yang sistematis, pengamatan yang cermat, dan umpan balik yang obyektif dan segera. Dengan cara itu guru dapat menggunakan balikan tersebut untuk memperhatikan kinerjanya. ${ }^{3}$ Jadi tujuan utama supervisi akademik adalah untuk meningkatkan kemampuan profesional guru dan meningktkan kualitas pembelajaran melalui pembelajaran yang baik.

Madrasah Tsanawiyah (MTs) Swasta Muhamadiyah Sukarame Bandar Lampung sebagai salah satu lembaga pendidikan Formal tingkat menengah, tidak terlepas dari masalah-masalah yang ada diantaranya: Kinerja guru dalam perencanaan pembelajaran, Kinerja guru dalam pelaksanaan pembelajaran, Kinerja guru dalam evaluasi pembelajaran, serta Kinerja guru dalam di siplin tugas. Di Madrasah ini terlihat adanya masalah kinerja guru dalam perencanaan pembelajaran. Dimana guru masih ada yang belum membuat persiapan pembelajaran sebelum mengajar. menyusun silabus tiap bidang pengembangan disekolah/madrasah atau mata pelajaran di sekoalah/madrasah berlandaskan standar isi, standar kompetensi dan kompetensi dasar, dan prinsip-prinsip pengembangan KTSP, Guru dalam pelaksanaan pembelajaran juga belum menggunakan strategi pembelajaran yang bervariasi sehingga yang terjadi pembelajaran terasa membosankan bagi siswa dan kinerja yang dihasilkan guru pun belum optimal. Selain itu guru-guru juga masih ada yang belum menggunakan media pembelajaran dalam melaksanakan pembelajaran. Dalam melakukan evaluasi pembelajaran. Penulis melihat guru hanya

${ }^{3}$ E Mulyasa, Manajemen \& Kepemimpinan Kepala Sekolah, (Jakarta: PT Bumi Aksara, 2012), h. 249 
melakukan evaluasi pada saat akan ujian. Ketika kegiatan pembelajaran di kelas guru tidak melakukan evaluasi, sehingga yang terjadi pada siswa selalu tidak ada persiapan untuk belajar di kelas.

Dari permasalahan-permasalahan yang disebutkan semua itu merupakan kegiatan supervisi akademik, baik dilakukan oleh pengawas maupun kepala madrasah. Hal inilah yang membuat penulis tertarik untuk melakukan penelitian dengan judul Pengaruh supervisi akademik terhadap kinerja guru MTs Swasta Muhammadiyah Sukarame Bandar Lampung. Maka dapat dirumuskan permasalahannya yaitu seberapa besar pengaruh supervisi akademik terhadap kinerja guru MTs Muhamadiyah Sukarame Bandar Lampung. Adapun hipotesis penelitian yaitu bahwa supervisi akademik berpengaruh positif terhadap kinerja guru MTs Muhamadiyah Sukarame Bandar Lampung.

\section{B. Metode Penelitian}

Jenis penelitian ini adalah penelitian deskriptif dengan pendekatan kuantitatif. Sedangkan objek dalam penelitian ini adalah tentang supervisi akademik dan kinerja guru MTs swasta Muhammadiyah Sukarame Bandar Lampung. Penelitian ini termasuk expost fakto yaitu penelitian yang dilakukan untuk mengetahui peristiwa yang telah terjadi dan kemudian menarik ke belakang, melalui data untuk menemukan faktor-faktor yang mendahului atau menemukan sebab-sebab. Adapun populasi penelitian yaitu guru MTs Muhamadiyah sukarame sebanyak 24 orang jadi penelitian ini penelitian total sampel. Dalam penelitian ini ada beberapa metode pengumpulan data yang 
penulis gunakan yaitu Angket dan dokumentasi sebagai alat pengumpul data yang primer. Analisis menggunakan rumus korelasi product Moment angka kasar yang sebelumnya dilakukan uji validitas dan reliabilitas setelah itu uji normalitas terlebih dahulu untuk menguji angket/kuesioner sebagai alat pengumpul data. Data yang diperoleh dianalisis dengan teknik korelasi sederhana dan uji ' $t$ '.

Analisis akan dilakukan melalui langkah-langkah pengolahan berupa: Data entry, Coding, Data Analysis. Data akan dianalisis secara kuantitatif untuk menguji hipotesis yang telah tersusun sebelumnya yaitu dengan menggunakan teknik analisis statistik dengan uji korelasi Product Moment dan uji ' $t$ ' untuk mengetahui pengaruh supervisi akademik terhadap kinerja guru.

\section{Landasan Teori \\ 1. Supervisi Akademik}

Supervisi dalam Dictionary of Education Good Carter (1959) yang dikutip oleh Prof . Drs. Piet A. Sahertian adalah usaha dari petugas-petugas sekolah dalam memimpin guru-guru dan petugas-petugas lainnya dalam memperbaiki pengajaran, termasuk menstimulasi, menyeleksi pertumbuhan jabatan dan perkembangan guru-guru serta merivisi tujuan-tujuan pendidikan, bahan pengajaran dan metode serta evaluasi pengajaran. ${ }^{4}$

Sedangkan Syaiful Sagala mengatakan Supervisi akademik sama maksudnya dengan konsep supervisi pendidikan (educational supervision) sering disebut pula sebagai instructional supervision atau instructional

${ }^{4}$ Piet A. Sahertian, Konsep Dasar \& Teknik Supervisi Pendidikan , (Jakarta: Rineka Cipta, 2008), h. 17 
leadership, yang menjadi fokusnya adalah mengkaji, menilai, memperbaiki, meningkatkan dan mengembangkan mutu kegiatan belajar-mengajar yang dilakukan guru melalui pendekatan bimbingan dan konsultasi dalam nuansa dialog profesional. ${ }^{5}$

Pendapat diatas menjelaskan bahwa supervisi akademik adalah kegiatan yang dilakukan oleh supervisor dengan memberikan bantuan untuk meningkatkan kualitas pembelajaran. Supervisi atau pengawasan merupakan bagian yang tidak bisa terpisahkan dari upaya untuk meningkatan prestasi belajar peserta didik dan mutu pembelajaran yang berkaitan dengan kinerja guru. Selanjutnya Mulyasa mengatakan supervisi akademik adalah bantuan profesional kepada guru, melalui siklus perencanaan yang sistematis, pengamatan yng cermat, dan umpan balik yang objektif dan segera. Dengan cara itu guru dapat menggunakan balikan tersebut untuk memperhatikan kenerjanya. ${ }^{6}$

Kegiatan supervisi akademik meliputi perencanaan, pelaksanaan dan penilaian proses pembelajaran yang dilaksanakan oleh guru. Oleh sebab itu sasaran supervisi akademik dimulai dari kegiatan perencanaan yang meliputi penyiapan perangkat pembelajaran, pelaksanaan yaitu bagaimana pelaksanaan proses pembelajaran yang berkaitan dengan penggunaan strategi/metode atau teknik pembelajaran, pengelolaan kelas, penggunaan media dan teknologi dalam pembelajaran, sampai dengan penilaian atau evaluasi terhadap proses

${ }^{5}$ Syaiful Sagala, Supervisi Pembelajaran, (Bandung : Alfabeta Bandung, 2012), h. 156 2012), h. 249 
pembelajaran. Jadi untuk melaksanakan supervisi akademik secara efektif maka diperlukan keterampilan yang profesional baik mengenai konseptual maupun interpersonal juga sekaligus terampil di sisi teknikal nya.

Dengan demikian maka dapat disimpulkan bahwa supervisi akademik merupakan pelaksanaan fungsi kepala sekolah/madrasah sebagai supervisor. Supervisi akademik dilaksanakan dalam rangka untuk meningkatkan kemampuan profesional guru dan optimalisasi pencapaian tujuan pembelajaran selain itu supervisi akademik juga bersifar pembinaan yang mengarah kepada perbaikan kualitas pembelajaran dikelas. Supervisi akademik dapat juga dilakukan oleh pengawas dengan tujuan perbaikan kualitas guru dan siswa.

Sedangkan tujuan diadakannya supervisi akademik yaitu untuk meningkatkan kualitas proses pembelajaran dalam rangka peningkatan kualitas hasil belajar siswa. Selain itu juga tujuan dari pada supervisi akademik yaitu untuk sharing bagi guru-guru mata pelajaran yang sejenis dan juga bagi guruguru lain, khususnya mengenai metode/strategi pembelajaran yang yang akan diterapkan sehingga dalam proses belajar mengajar tetap selalu aktif dan suasana kelas tetap selalu kondusif.

Supervisi akademik mempunyai prinsip-prinsip yang harus direalisasikan pada setiap proses supervisi akademik disekolah-sekolah atau madrasah yaitu sebagai berikut :

a. Supervisi akademik harus mampu menciptakan hubungan kemanusiaan yang harmonis, bersifat terbuka, kesetiakawanan, dan informal, hubungan demikian ini bukan saja anatara supervisor dengan guru, 
melainkan juga antara supervisor dengan pihak lain yang terkait dengan program supervisi akademik.

b. Supervisi akademik harus dilakukan secara berkesinambungan. Supervisi akademik bukan tugas bersifat sambilan yang hanya dilakukan sewaktu-waktu jika ada kesempatan. Apabila guru telah berhasil mengembangkan dirinya tidaklah berarti selesailah tugas supervisor melainkan harus tetap dibina secara berkesinambungan. Hal ini logis, mengingat problema proses pembelajaran selalu muncul dan berkembang.

c. Supervisi akademik harus demokratis. Supervisi tidak boleh mendominasi pelaksanaan supervisi akademiknya. Titik tekan supervisi akademik yang demokratis, aktif dan kooperatif. Supervisor harus melibatkan secara aktif guru yang dibinanya. Tanggung jawab perbaikan program akademik bukan hanya pada supervisor melainkan juga pada guru. Karena itu program supervisi akademik sebaiknya direncanakan, dikembangkan dan dilaksanakan bersama secara kooperatif dengan guru, kepala sekolah dan pihak lain yang terkait di bawah koordinator supervisor.

d. Program supervisi akademik harus integral dengaan program pendidikan secara keseluruhan. Dalam upaya perwujudan prinsip ini diperlukan hubungan yang baik dan harmonis antara supervisor dengan semua pihak pelaksana program pendidikan.

e. Supervisi akademik harus komprehensif . program supervisi akademik harus mencakup keseluruhan aspek pengembangan akademik, 
walaupun mungkin saja ada penekanan pada spek-aspek tertentu berdasarkan hasil analisis kebutuhan pengembangan akademik sebelumnya.

f. Supervisi akademik harus konstruktif. Supervisi akademik bukanlah untuk mencari kesalahaan-kesalahan guru, melainkan untuk mengembangkan pertumbuhan dan kreativitas guru dalam memahami dan memecahkan problem-problem akademik yang dihadapi.

g. Dalam menyusun, melaksanakan dan mengevaluasi, keberhasilan program supervisi akademik harus obyektif berdasarkan kebutuhan nyata pengembangan professional guru

\section{Kinerja Guru}

Siagian berpendapat bahwa kinerja merupakan suatu pencapaian pekerjaan tertentu yang akhirnya secara langsung dapat tercermin dari keluaran yang dihasilkan. ${ }^{7}$ Anwar Prabu Mangkunegara mengatakan Istilah kinerja guru berasal dari kata job performance/actual permance (prestasi kerja atau prestasi sesungguhnya yang dicapai oleh seseorang). Jadi menurut bahasa kinerja bisa diartikan sebagai prestasi yang nampak sebagai bentuk keberhasilan kerja pada diri seseorang. ${ }^{8}$ Keberhasilan kinerja juga ditentukan dengan pekerjaan serta kemampuan seseorang pada bidang tersebut. Keberhasilan kerja juga berkaitan dengan kepuasan kerja seseorang. Prestasi kerja atau penampilan kerja (performance) menurut Fattah adalah sebagai

7 Siagian Sondang P, Kiat meningkatkan produktivitas kerja (Jakarta : Rineka , 2002), h.327

8 Anwar Prabu Mangkunegara, Manajemen Sumber Daya Manusia, (Bandung : Rosdakarya,, 2000), h. 67 
ungkapan kemampuan yang didasarkan oleh pengetahuan, sikap, keterampilan dan motivasi dalam menghasilkan sesuatu . ${ }^{9}$

Dengan demikian maka yang dimaksud dengan kinerja guru adalah seluruh aktivitas yang dilakukan oleh seorang guru dalam mengemban amanat dan tanggung jawabnya dalam mendidik, mengajar dan membimbing, mengarahkan, serta memandu peserta didik untukmencapai tingkat kedewasaan dan kematangannya. Jelaslah bahwa kinerja guru pada dasarnya lebih terarah kepada perilaku seorang pendidik dalam pekerjaannya menjalankan tugas dan tanggungjawabnya sebagai sebagai pendidik sehingga dapat memberikan pengaruh yang besar terhadap peserta didik untuk mencapai tujuan yang diinginkan.

Sedangkan Faktor -faktor yang mempengaruhi kinerja atau keberhasilan kerja ditentukan oleh faktor-faktor internal dan eksternal. Faktor internal adalah faktor yang berasal dari diri guru, diantaranya: kemampuan, kepribadian, motif/motivasi, kecerdasan, Kompetensi, Cita-cita, Tujuan bekerja, Kesehatan, Minat, Bakat, Disiplin kerja, Komitmen.

Faktor eksternal adalah faktor-faktor yang berasal dari luar lingkungan guru, diantaranya: Lingkungan keluarga, Lingkungan Kerja, Sarana Prasarana, Kominikasi, Penghargaan, Insentif, Iklim Organisasi, Diklat, Peran serta Orang tua, dan Peran serta masyarakat. ${ }^{10}$

9 Nanang Fattah, Ekonomi dan Pembiayaan Pendidikan, (Bandung : Remaja Rosdakarya, 2000), h. 19

10 A. Dale Timpe, The Art and Science of Business Management: Leadership, (New York: Kend Pub, Inc., 2000), h. 32. 
Selanjutnya Syaiful Sagala menyatakan bahwa karakteristik kinerja guru adalah :

a. Pengorganisasian mata pelajaran yang baik

b. Komunikasi yang efektif dalam pembelajaran dan manajemen madrasah

c. Pengetahuan dan keingintahuan terhadap mata pelajaran dan sikap pengajaran

d. Sikap positif terhadap peserta didik

e. Penilaian yang fair dalam hal penjenjangan atau penentuan peringkat

f. Pendekatan yang fleksibel terhadap pengajaran

g. Hasil belajar peserta didik yang layak dan pantas sesuai kinerja madrasah. ${ }^{11}$

Dari pendapat diatas dapat disimpulkan bahwa karakteristik kinerja guru dapat digolongkan kedalam tiga kegiatan yaitu:

1. Mendidik, hal ini tidak terlepas dari kegiatan seorang guru harus selalu memberikan contoh dan teladan bagi siswanya karena mendidik adalah suatu usaha sadar yang dilakukan oleh orang dewasa untuk membentuk prilaku anak didik yang kelak menjadi pribadi yang bertanggungjawab, mandiri serta berakhlakul karimah.

2. Mengajar, yaitu merupakan kegiatan yang dilakukan oleh guru dari mulai mempersiapkan persiapan mengajar sperti RPP, media, metode yang variatif dan penguasaaan terhadap proses belajar 
mengajar serta kegiatan evaluasi, yang kesemuanya harus dikuasai oleh guru tersebut.

3. Melatih, hal ini seperti pembiasaan yang dianjurkan kepada siswa untuk selalu mematuhi peraturan atau tata tertib di sekolah atau madrasah, membiasakan peserta didik untuk selalu disiplin di dalam kelas dengan selalu mengikuti proses pembelajaran, melatih siswa untuk dapat bekerjasama dengan orang lain atau dengan masyarakat lain.

Dari uraian diatas maka jelaslah bahwa kinerja guru tersebut tidak akan berkembang atau meningkat bila tidak ada upaya baik dari guru yang bersangkutan yang merupakan tangung jawab maupun dari pihak luar seperti kepala sekolah atau madrasah yang akan selalu memantau semua aktivitas atau kegiatan guru selama bertugas disekolah, seperti yang dikatakan Hamzah Uno yaitu kemampuan yang dimiliki seseorang dibentuk berdasarkan pengalaman yang diperoleh secara emperis melalui observasi, pengetahuan ilmiah yang diterimanya dari pendidikan formal, dan keterampilan yang dilakukannya secara mandiri. $^{12}$

\section{Kerangka Berpikir}

Berdasarkan kajian teori di atas maka kinerja guru dapat disimpulkan kemampuan yang ditunjukkan oleh guru dalam melaksanakan tugas atau pekerjaannya. Kinerja dikatakan baik dan memuaskan apabila tujuan yang dicapai sesuai dengan standar yang telah ditetapkan. Oleh karena itu kinerja

12 Hamzah B Uno, Profesi Kependidikan: Problema, Solusi dan ReformasiPendidikan di Indonesia, (Jakarta : Bumi Aksara, 2008), h.60 
adalah merupakan suatu kegiatan dalam melaksanakan tugas yang dilakukan oleh setiap guru untuk mencapai tujuan sesuai dengan aturan yang telah ditetapkan.

Kinerja guru pada dasarnya Merupakan kinerja atau unjuk kerja yang dilakukan oleh guru dalam melaksanakan tugasnya sebagai pendidikan kualitas, kinerja guru akan sangat menentukan pada kualitas hasil pendidikan karena guru merupakan pihak yang paling banyak bersentuhan langsung dengan siswa dalam proses pendidikan/pembelajaran di lembaga pendidikan sekolah dan untuk memahami apa dan bagaimana kinerja guru itu.

Kinerja guru mempunyai spesifikasi tertentu. Kinerja guru dapat dilihat dan diukur berdasarkan spesifikasi atau kriteria kompetensi yang harus dimiliki oleh setiap guru. Berkaitan dengan kinerja guru, wujud perilaku yang dimaksud adalah kegiatan guru dalam proses pembelajaran.

Kinerja guru dapat dilihat saat dia melaksanakan interaksi belajar mengajar di kelas termasuk persiapannya baik dalam bentuk program semester maupun persiapan mengajar.

Dengan demikian maka dapat disimpukan bahwa Kinerja Guru adalah merupakan suatu proses kerja guru berdasarkan kemauan dan kemampuannya dalam melaksanakan tugas yang dibebankan kepadanya antara lain tentang perencanaan mengajar, pelaksanaan pembelajaran dan lainnya.

Selanjutnya faktor-faktor yang mempengaruhi kinerja tersebut banyak sekali diantaranya adalah faktor supervisi atau pengawasan yang dilakukan oleh para pengawas yang ditunjuk oleh kemendiknas dan juga dilakukan oleh kepala sekolah/madrasah yang bertindak sebagai pengawas. Hal ini berkaitan 
dengan supervisi akademik yang dimulai dari kegiatan perencanaan yang meliputi penyiapan perangkat pembelajaran, pelaksanaan yaitu bagaimana pelaksanaan proses pembelajaran yang berkaitan dengan penggunaan strategi/metode atau teknik pembelajaran, pengelolaan kelas, penggunaan media dan teknologi dalam pembelajaran, sampai dengan penilaian atau evaluasi terhadap proses pembelajaran. Jadi untuk melaksanakan supervisi akademik secara efektif maka diperlukan keterampilan yang profesional baik mengenai konseptual maupun interpersonal juga sekaligus terampil di sisi teknikal nya

Dengan demikian maka dapat dikatakan bahwa semakin baik supervisi akademik maka akan semakin baik pula kinerja guru tersebut, sebaliknya semakin buruk supervisi akademiknya maka akan semakin buruk pula kinerja guru tersebut. Pola hubungan ini dapat dilihat dalam gambar di bawah ini :

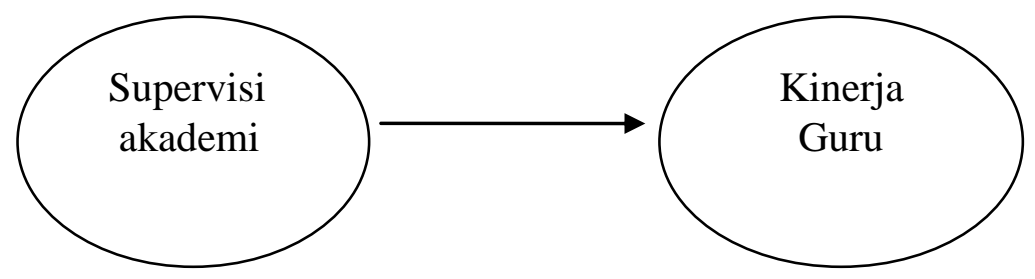

\section{Hasil}

Berdasarkan data diatas ditemukan adanya pengaruh positif antara supervisi akademik terhadap kinerja guru MTs Muhammadiyah Sukarame Bandar Lampung. Pemahaman yang terkandung dalam kontek ini adalah semakin baik pelaksanaan supervisi akademik maka semakin baik pula kinerja 
gurunya, hubungan kedua variabel tersebut ditunjukkan oleh adanya koefisien korelasi sebesar $r_{\text {tabel }}<r_{\text {hitung }}$ atau 0,404<0,843 ( @=0,05, $n=24$ ) dan koefisien determinasi sebesar 7,354 yang berarti bahwa supervisi akademik memberikan kontribusi sebesar 73,54\% terhadap kinerja guru. Dengan kata lain supervisi akademik secara nyata ikut menentukan dan memberikan sumbangan atau kontribusi terhadap kinerja guru pada MTs Muhammadiyah Sukarame Bandar Lampung.

\section{E. Simpulan}

Dari hasil kesimpulan dinyatakan bahwa terdapat pengaruh yang signifikan antara supervisi akademik dengan kinerja guru. Sebagai implikasinya, jika kita ingin meningkatkan kinerja guru maka perlu adanya upaya untuk meningkatkan supervisi akademik. Oleh karena itu diperlukan upaya untuk meningkatkan pelaksanaan tentang kegiatan supervisi akademik yaitu yang berkaitan dengan persiapan mengajar, seperti silabus, Rencana pelaksaanaan pembelajaran (RPP), persiapan metode, strategi dan juga media pembelajarannya, selanjutnya kegiatan evaluasi juga perlu dipersiapkan yang kesemuanya itu dapat meningkatkan kinerja guru.

Berdasarkan kesimpulan di atas maka jika supervisi akademik terhadap guru ditingkatkan maka akan meningkat pula kinerjanya. Hal ini menunjukkan bahwa guru tanpa adanya supervisi akademik maka akan mempunyai kinerja yang rendah. Dengan demikian maka hal ini memperkuat hasil bahwa supervisi akademik juga turut menentukan dalam meningkatkan kinerja guru. 
Berdasarkan uraian di atas maka disarankan perlu adanya kesepakatan mengenai rumusan definisi operasional tentang supervisi akademik dan kinerja guru, agar para guru dapat memahami hakekat dari pada supervisi akademik dan kinerja guru yang akhirnya kelak akan memiliki kinerja guru yang tangguh.

Selanjutnya kegiatan supervisi akademik perlu ditingkatkan lagi baik oleh kepala sekolah maupun kepada pengawas untuk ditambahnya waktu kunjungan ke madarasah tersebut dalam rangka penyusunan RPP dan lainlainnya mengingatnya masih banyaknya hal-hal yang harus diterapkan dalam mengikuti kurikulum 2013.

\section{DAFTAR PUSTAKA}

Anas Sudijono, 2011, Pengantar Statistik Pendidikan,, (Jakarta :Raja Grafindo Persada.

Anwar Prabu Mangkunegara, 2000, Manajemen Sumber Daya Manusia, Bandung : Rosdakarya.

Arikunto, Suharsimi. 2002. Prosedur Penelitian Suatu Pendekatan Praktek. Jakarta: PT Rineka Cipta.

August W. Smith, 1997, The Quality Audit Handbook, Wisconsin : ASQC.

A. Dale Timpe, 2000, The Art and Science of Business Management: Leadership, New York: Kend Pub, Inc.

M Ngalim Purwanto, 2003, Administrasi dan Supervisi Pendidikan Bandung: Remaja Rosdakarya, 2003),

Muhtar. 2003, Desain Pembelajaran Pendidikan Agama Islam, Jakarta : Misaka Galiza.

Mulyasa E,2012, Manajemen \& Kepemimpinan Kepala Sekolah, Jakarta: PT Bumi Aksara.

Mulyasa E, 2006, Menjadi Guru Profesional Menciptakan Pembelajaran Kreatif Dan Menyenangkan. Bandung : Remaja Rosdakarya. 
Mulyasa E, 2003, Manajemen Berbasis Sekolah, Bandung : Remaja Rosdakarya.

Nanang Fattah, 2000, Ekonomi dan Pembiayaan Pendidikan, Bandung : Remaja Rosdakarya.

Norman E. Gronlund, 1982, Constructing Achievement Tests, Third Edition, London: Prentice-Hall, Inc. Englewood Cliffs.

Peter F. Drucker, 2000. The Organization of The Future, (New York: JosseyBass, Inc.

Piet A Sahertian, 2008, Konsep Dasar\&Teknik Supervisi Pendidikan, Jakarta : Rineka Cipta.

Peraturan Pemerintah RI No. 19 Tahun 2005, Tentang Standar Nasional Pendidikan, Jakarta CV. Eko Jaya.

Purwanto, M. Ngalim, 2002, Administrasi Pendidikan, Jakarta: PT Remaja Rosdakarya

Siagian, Sondang, 2002, Kiat meningkatkan produktivitas kerja Jakarta : Rineka.

Sugiyono,2009, Metode Penelitian Kuantitatif Kualitatif Dan $R \& D$, Bandung : Alfabeta.

Suharsimi Arikunto,Suharjono dan Supardi, 2007, Penelitian tindakan Kelas,, Jakarta :Bumi Aksara,

Sutrisno Hadi, 1984, Metode Research, Jilid II, Fakultas Psikilogi UGM Yogyakarta.

Syaiful Sagala, 2012 Supervisi Pembelajaran, Bandung : Alfabeta.

Syaiful Sagala, 2007, Manajemen Strategik Dalam Peningkatan Mutu Pendidikan, Bandung : Alfabeta.

Syafruddin Nurdin dkk, 2002, Guru Profesional \& Implementasi Kurikulum, Jakarta : Ciputat Press.

Suryosubroto, 2004, Manajemen Pendidikan di Sekolah,, Jakarta : Rineka Cipta.

Undang-Undang SISDIKNAS, 2003 (UU RI No 20 Th.2003), Jakarta : Sinar Grafik. 